\title{
Bio-interaction of Agrobacterium rhizogenes with Capsicum annuum L. (sweet variety) and Establishment Hairy Roots Cultures
}

\author{
Qutaiba S. AL-Nema \\ Department of Biology, Laboratory of Plant Genetic Manipulation, College of Education for Pure Sciences, University \\ of Mosul, Iraq. \\ * Correspondence: dr.qutaibashuaib@uomosul.edu.iq
}

\begin{abstract}
Genetic transformation using Agrobacterium is one of the techniques used to transfer desired genes to plants. This protocol is considered a short - cut to get transformed plants which could be an alternative method and suitable system compared with the classical methods. This study aimed to investigate the response of $C$. annuum seedlings (sweet variety) to the formation transformed hairy roots induced by A. rhizogenes strain R1601. Sterilized seeds of Capsicum annuum were inoculated with the Agrobacterium rhizogenes inoculum. The samples were then transferred to the surface of solidified MS medium. Hairy roots were developed at the inoculation sites and were enucleated $1.0-1.5 \mathrm{~cm}$ length and placed in $9.0 \mathrm{~cm}$ Petri-dishes containing $15 \mathrm{ml}$ of agar solidified MS medium. Agropine test was performed according to the standard method. The inoculated seedlings showed a good response $90 \%$. Transformed hairy roots were established at the injection sites within 10 days and these roots were easily grown on agar-solidified MS medium. The results are confirmed that these roots were transformed roots it in terms of positive agropine detection. The current study concluded that the biological interaction between Agrobacterium rhizogenes strain R1601 and Capsicum anuum L. seedlings, was successful. This study encourages future research to improve this plant by continuing and applying modern technologies to obtain genetically modified plants.
\end{abstract}

Keywords: Agrobacterium rhizogenes, Hairy roots formation, Capsicum annuum, pepper

Received: August $9^{\text {th }}, 2020 /$ Accepted: September $10^{\text {th }}, 2020 /$ Online: September $15^{\text {th }}, 2020$.

\section{INTRODUCTION}

Capsicum annuum is an economically and medicinally important crop at the same time. Pepper plants have different varieties including Bird Pepper, Chilli Pepper, Hot Pepper, Red Chilli, Spur Pepper and Tabasco Pepper (Duke, 2003). The sweet Pepper are widely used in food because they contain a high content of vitamin C (Stroev, 1989). Chilli pepper is used externally as a tonic and anti-irritant, and it is used internally as an aid to digestion and a repellent of gases (Libster, 2002). The economic and medicinal importance of this plant encourages conducting research with the aim of improving its varieties, such as conducting electrical fusion between protoplasts of two differentvarities (Al- Nema and Al- Mallah, 2020).

Green pepper is a major source of vitamin $\mathrm{C}$ and also contains a group of enzymes, including peroxidase (Cuenca et al., 1989). Agrobacterium have a unique ability to transfer parts of their genetic material and insert it into the genome of plant cell (Georgiev et al., 2008). The ability of this bacterium to interfere with plants in nature was exploited by using it, they were used in the process of genetic transformation into a number of dicotyledonous plants (Kifle et al., 1999). The ability of Agrobacterium strains to cause plant diseases is due to their relatively large plasmids (200-800 kbp). A. rhizogenes have a large root inducing plasmids so called Ri plasmids (Veena and Taylor 2007), and causes hairy root disease in infected plants (Weller et al. 2005).

The bacteria of this genus can be divided according to their composition of the unusual amino acids known as the opine group, as the plant cells infected with bacteria form these amino acids, which are used by the bacteria as a source of energy (Bundock and Hooykaas, 1998). This bacterium mediated gene transfer is widely used to obtain hairy roots in many plant species as in sugarbeet (Al- Mallah and AlNema, 2001), carrot (AL-Mallah and Mohammed, 2012), Fenugreek (AL-Mahdawe et al., 2013), cowpea (Rasheed and Abdullah, 2013) and Rue (AL-Mahdawe et al., 2020). The present study aims is to investigate the response of $C$. 
annuum seedlings (sweet variety) to the formation transformed hairy roots induced by $A$. rhizogenes strain R1601.

\section{MATERIALS AND METHODS}

\section{A. Seeds sterilization and germination}

Seeds of Capsicum annuum (sweet variety) were surface sterilized by immersing them in a $6 \%$ of $\mathrm{NaOCl}$ at a concentration of $(1: 1, \mathrm{~V}: \mathrm{V})$ with distilled water (ALYozbaki, 1998). Sterilized seeds were transferred to the surface of solidified MS medium (Murashig and Skoog, 1962). Plantlets were kept under growth room condition $25 \pm 2^{\circ} \mathrm{C}$ with light intensity of 1000 Lux, with a daily 16 hs. photoperiod.

\section{B. Source and preparing of bacterial inoculum}

R1601 strain of Agrobacterium rhizogenes was used, supplied from Professor E. W. Nester Washington University, USA, which is a genetically modified strain that has genetic markers that include resistance to the antibiotics Kanamycin (Kana. $\mathrm{R}^{+}$) and Carbencillin (Carb. $\mathrm{R}^{+}$). Cultures were grown on APM agar solidified medium (Morgan et al., 1987). The bacterial inoculum was prepared by transferring one colony of $A$. rhizogenes into a $50 \mathrm{ml}$ flask containing 20 $\mathrm{ml}$ liquid APM medium and incubated in shaking incubator at $28 \pm 1^{\circ} \mathrm{C} / 150 \mathrm{rpm}$ in dark (Al- Mallah and Al- Nema, 2001). After 24 hours of incubation, the culture was harvested by centrifugation for $15 \mathrm{~min}$. at $1200 \mathrm{rpm}$. Pour off the supernatant, and re-suspend the pellet to a final OD of 1.90-2.00 for inoculation of seedlings.

\section{Inoculation of seedlings with Agrobacterium rhizogenes}

Sterilized seedlings (two weeks old) were pricked at 3 site/plant after removing the root group from it. Samples (50 seedlings) were inoculated with a sterile $0.25 \times 9.5 \mathrm{~mm}$ Needle whose fine tip was submerged in the bacterial inoculum, as well as other 50 seedlings (control samples) were pricked by sterile needle without bacteria. The samples were then transferred to the surface of solidified MS medium and stored in the culture room at $25 \pm 2^{\circ} \mathrm{C}$ with light intensity of 100 Lux.

\section{Development of hairy root cultures}

Hairy roots were developed at the inoculation sites after 10 days. Young hairy roots were enucleated 1.0-1.5 cm length and placed in $9.0 \mathrm{~cm}$ diam. plastic Petri-dishes containing 15 $\mathrm{ml}$ of agar solidified MS medium at a rate of 5 strands / plate, the plates were covered with lids and sealed with parafilm strips (Al- Mallah and Al- Nema, 2001). And the samples were kept under the same previous conditions.

\section{E. Agropine test}

Agropine test was performed according to the standard method (Tepfer and Tempé, 1981). $100 \mathrm{mg}$ of hairy roots and normal roots were crushed separately in the presence of $0.1 \mathrm{~N} \mathrm{HCl}$, and the samples were centrifuged at $12.000 \mathrm{~g} /$ $10 \mathrm{~min} .20 \mu \mathrm{l}$ of each sample and standard agropine was spotted on Whatman No.3 mm paper $(15 \times 30 \mathrm{~cm})$ and subjected to electrophoresis $300 \mathrm{~V} / \mathrm{cm}, 60 \mathrm{~min}$. Electophotogram was stained with silver nitrate $\left(\mathrm{AgNO}_{3}\right)$ for 15-30 min, then immerged in 2\% methanolic $\mathrm{NaOH}$, dried and submerged with $5 \% \mathrm{Na}_{2} \mathrm{~S}_{2} \mathrm{O}_{3}$. Finally washed with tap water for $30 \mathrm{~min}$ and then allowed to air dry.

\section{Results}

\section{A. Interaction between Agrobacterium rhizogenes and Capsicum annuum}

The biological interaction process was succeeded between A. rhizogenes $\mathrm{R} 1601$ and $C$. annuum seedlings. Hairy roots were developed from injected sites on seedlings after 10 days (Figure 1, a). The number hairy roots formed on each seedling was 2-5 roots. After sequential transfer of these roots on solid MS medium they were obtained after two weeks (Figure 1, b). These adventitious hairy roots were negatively geotropism in their growth with dense of root hairs (Figure 1, c). Moreover, the responses of seedlings to inoculation by $A$. rhizogenes was $90 \%$ compared with the control samples that did not show any response (Table 1).
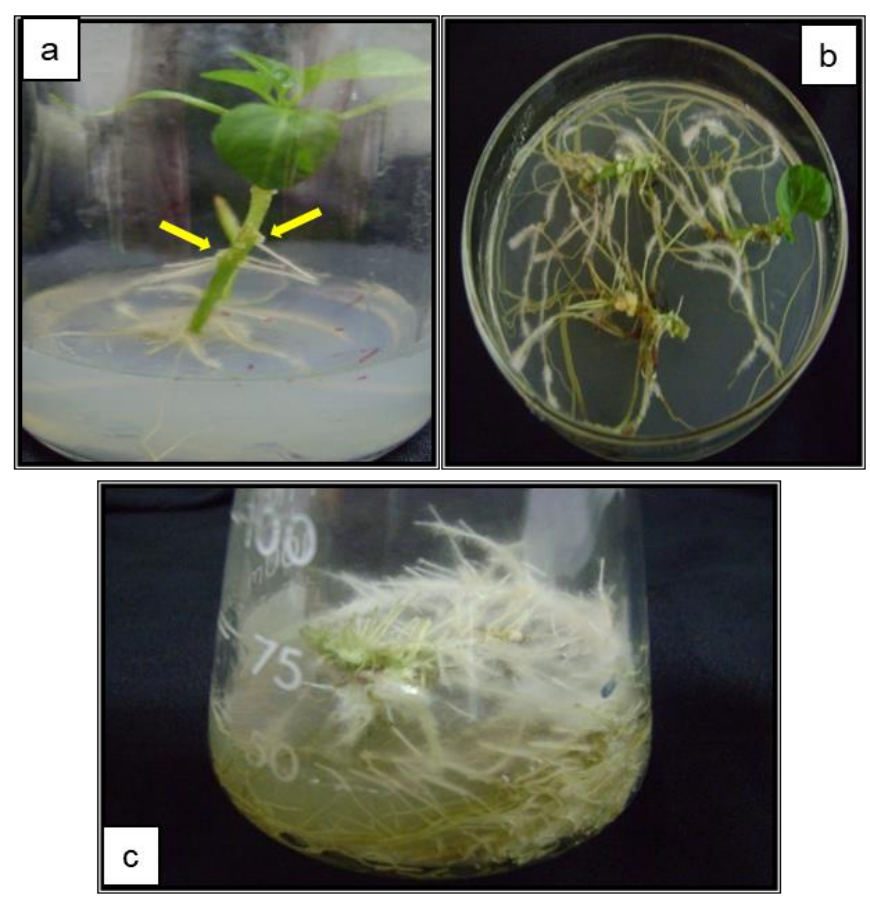

Figure 1. Transformed hairy roots formation on Capsicum annuum seedlings (sweet variety) inoculated via Agrobacterium rhizogenes 1601. a. Hairy roots formed on pepper seedlings at injection sites (10 days old) on solidified MS medium (arrowed). b. Hairy roots developed on seedlings (two weeks old). c. Culture of hairy roots having dense root hairs on solidified MS medium (6 weeks old). 
Table 1. Transformed hairy roots production on paper capsicum annuum seedlings inoculated by Agrobacterium rhizogenes

\begin{tabular}{|c|c|c|c|c|}
\hline Treatment & $\begin{array}{c}\text { Number of } \\
\text { seedlings } \\
\text { inoculated }\end{array}$ & $\begin{array}{c}\text { Number of } \\
\text { seedlings } \\
\text { forming } \\
\text { roots }\end{array}$ & $\begin{array}{c}\text { Average no. } \\
\text { of hairy } \\
\text { roots / } \\
\text { seedling }\end{array}$ & $\begin{array}{c}\text { Hairy root } \\
\text { formation } \\
\%\end{array}$ \\
\hline Seedlings & 50 & 45 & 3.52 & 90 \\
\hline Control & 50 & 0 & 0 & 0 \\
\hline
\end{tabular}

B. Agropine test as evidence of genetic transformation.

The results of paper electrophoresis showed positive detection of agropine in the hairy root samples, while the normal root samples gave a negative detection of this test. A single spot was formed for the hairy root samples corresponding to its location to the standard agropine spot, while the normal root samples did not give any spot (Figure 2).

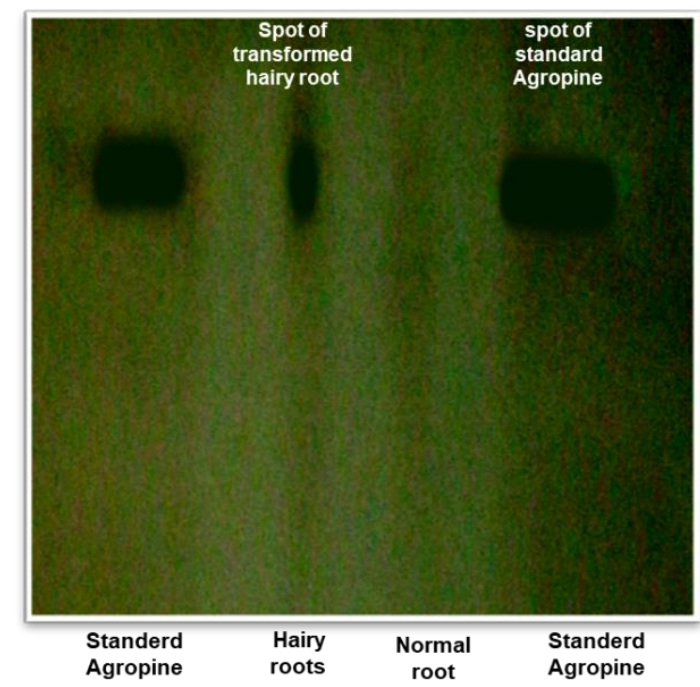

Figure 2. Chromatography sheet showing the spots of standerd agropine and agropine in transformed hairy roots induced on capsicum annuиm seedlings by Agrobacterium rhizogenes 1601

\section{DISCUSSION}

The study included identifying the response of sweet pepper plants to a system of genetic transformation using strain R1601 of $A$. rhizogenes. The high response to pepper seedlings through their tolerance to direct injection of bacteria and their formation of hairy roots confirms the possibility of using this system and the response of plants to it (Hansen and Wright, 1999).

The success of the inoculation process by direct injection with this genetically modified bacterium containing $\mathrm{Ri}$ plasmids is due to the transfer of T-DNA segment containing the genes responsible for the formation of hairy roots and its random interference with the genotype of the plant cell (Vergunst and Hooykaas, 1999).

In this type of roots that is formed by the presence of genes responsible for making agropine (unusual amino acids) transferred on T-DNA segment into the genome of the transformed cells (AL-Mahdawe et al., 2013). The rapid growth of transformed hairy roots and its dense content of root hairs, may due to the length of apical meristem for these roots compared with untransformed roots (Meyer, et al., 2000). The development of transformed hairy roots on various plant species are involving different time, like 15 days of inoculation in Solanum nigrum (Al-Mallah and Salih, 2006), and 4 weeks in Beta vulgaris (Al-Mallah and Al-Nema, 2012).

\section{V.CONCLUSION}

The current study concluded that the biological interaction between Agrobacterium rhizogenes strain R1601 and Capsicum anuum L. seedlings, was successful. Therefore, this study encourages conducting future research aimed at improving this economically important plant by continuing and applying modern technologies to obtain genetically modified plants.

\section{REFERENCES}

Al-Mahdawe, M.M.; Al-Mallah, M.K., Al-Attrakkchii, A.O. (2013). Genetically transformed hairy roots producing agropine induced on Trigonella foenumgraecum L. plant by Agrobacterium rhizogenes 1601. IJFMT., 14: 858864.

Al-Mahdawe, M.M., Al-Mallah, M.K., Al-Nema, Q.S. (2020). Expression and Conservation of rol-genes in Rue, Ruta graveolens L., Plants Regeneration from Hairy Roots. J. Biotech. Res. Cent., 7: 91-98.

Al-Mallah, M.K., Al-Nema, Q.S. (2001). Production of transformed hairy roots on explants of sugarbeet by Agrobacterium rihzogenes R1601. J. Biotech. Res., 3(2):71-81.

Al-Mallah, M.K., Al-Nema, Q.S. (2012). Putative genetically modified callus derived from transformed hairy roots induced on sugarbeet (Beta vulgaris) explants by Agrobacterium rihzogenes 1601 harbouring Ri-plasmid. Iraqi J. Biotech., 11 (2):455-463.

Al-Mallah, M.K., Mohammed, A.A. (2012). Transfer of Ri T-DNA genes of Agrobacterium rhizogenes R1601 via direct microinjection and cocultivation to carrot, Daucus carota L., tissue and production of transformed hairy root cultures. Iraq J. Biotech., 11:227-239.

Al-Mallah, M.K., Salih, S.M. (2006). An efficient technique for obtaining Solanum nigrum plants via transformation by Agrobacterium rihzogenes 1601. Raf. J. Sci., 17: 92-107.

Al-Nema, Q.S., Al-Mallah, M.K.(2020). Electrofusion of msophyll protoplasts from two varietiesof sugarbeet, (Beta vulgaris). JLBSR. 1(1): 22-25.

Al-Yuzbaki, G.S.Y. (1998). The content of vitamin C and the alkaloid capsaicin in the vegtative parts and the emerging callus of Capsicum annuиm L. (sweet and spicy variety). Master Thesis, College of Education, University of Mosul. 9IN Arabic).

Bundock, P., Hooykaas, P.J.J. (1998). Interaction between Agrobacterium tumefaciens and plant cells: In Phytochemical Signals and Plants Microbe Intraction. Vol. 32, ed. by Romeo; Downum and Verpoorte. Plenum Press. New York.

Cuenca, J., Garcia-florenciano, E., Barcelo, A.R., Munz, R. (1989). Sequential release of both basic and acidic isoperoxidases to the media of suspension cultured cells of Capsicum annuum. Plant Cell Repts., 8:471474. (C.F.(Al-Yozbaki,1998).

Duke, J.A. (2003). CRC Hand Book of Medicinal Spices. CRC Press LLC. USA.

Georgiev, M., Georgiev, V., Weber, J., Bley, Th., Ilieva, M., Pavlov, A. (2008). Agrobacterium rhizogenes-mediated genetic transformation: A powerful tool for the production of metabolites. In: Genetically Modified Plants, (T. Wolf and J. Koch edits.); Nova Science Publishers, Hauppauge, NY, USA, ISBN: 978-1-60456-696-3, pp. 99-126

Hansen, J.D., Wright, M. (1999). Recent advances in the transformation of plants. Trends in Plant Sci., 4: 226-231.

Kifle, S., Shao, M., Jung, C., Cai, D. (1999). An improved transformation protocol for studying gene expression in hairy roots of sugar beet (Beta vulgaris). Plant Cell Repts. 18: $514-519$.

Libster, M. (2002). Delmar's Integrative Herb Guide for Nurses. DelmarThomson Learning. Albany. N. Y. 
Meyer, A.D., Tempe, J., Costantino, P. (2000). Hairy root: A molecular overview. Plant Microbe Inter. 5:1-39.

Morgan, A.J., Cox, P.N., Turner, D.A., Peel, E., Davey, M.R., Garthand, K.M., Mulligan, B. (1987). Transformation of tomato using an Riplasmid Vector. Plant Sci. 49:37-49.

Murashige, T., Skoog, F. (1962). A revised medium for rapid growth and bioassays with tobacco tissue culture. Physiol. Plant. 15: 473-497.

Rasheed, J.H., Abdullah, R.M. (2013). Recovery of transgenic cowpea (Vigna radiate L.) plants from hairy roots produced by Agrobacterium rhizogenes R1601. Aust. J. Bas. \& App. Sci., 7 (12): 192-196.

Stroev, E.A. (1989). Biochemistry. MIR Publishers. Moscow.

Tepfer, D.A., Tempe, J. (1981). Production of di-agropine par des vacines formees sous I'action Agrobacterium rhizogenes. Acad. Sci. Paris. Ser. III, 292: 212-218.

Veena, V., Taylor, C.G. (2007). Agrobacterium rhizogenes: recent developments and promising applications. In Vitro Cell Dev Biol Plant, 43:383-403

Vergunst, A.C., Hooykaas, P.J.J. (1999). Recombination in the plant genome and its application in biotechnology. Critical Reviews in Plant Sci., 18:1-13.

Weller, S.A., Stead, D.E., Young, J.P.W. (2005). Induction of root-mat symptoms on cucumber plants by Rhizobium, but not by Ochrobactrum or Sinorhizobium, harbouring a cucumopine $\mathrm{Ri}$ plasmid. Plant Pathol., 54:799-805. 